日作紀（Jpn. J. Crop Sci.） 86（1）：7-14（2017）

\title{
東北農研が育成した水稲品種における窒素追肥時期が 生育・収量・外観品質・食味に及ぼす影響
}

\author{
福嶌陽・太田久稔・横上晴郁・津田直人 \\ (農研機構東北農業研究センター)
}

\begin{abstract}
要旨：農研機構東北農業研究センターが育成した中食・外食向けの水稲 3 品種「ちほみのり」,「萌えみのり」,「えみ のあき」における窒素追肥の効果を調査した。早生品種群として，「まっしぐら」，「ちほみのり」，「あきたこまち」, 中生品種群として,「ひとめぼれ」,「萌えみのり」,「えみのあき」を用いた。いずれの品種群も, 前期追肥区, 後期 追肥区，無追肥区を設けた，東北農研が育成した 3 品種の窒素追肥に対する反応性は，他品種と大きく異ならなかっ た，そこで，品種によらない窒素追肥に対する反応性，および，窒素追肥によらない 3 品種の特性について解析した. いずれの品種群においても, 前期追肥により, 穂数が増加し, 総籾数が増加することにより精玄米重が増加した. 後 期追肥により, 総籾数がやや増加し, 千粒重がやや増加することによって精立米重が増加した。 しかし, 前期追肥では, 乳白粒が増加し, 外観品質が低下した。後期追肥では, 玄米の蛋白質含量が増加し, 食味がやや低下した. 収量, 外 観品質, 食味を総合的にみて, 東北農研が育成した 3 品種においては中間時期の追肥が適切と推察された。東北農研 が育成した 3 品種の精玄米重は,「ちほみのり」が「あきたこまち」と同程度,「萌えみのり」が「ひとめぼれ」より やや多く,「えみのあき」が「ひとめぼれ」よりやや少なかった。これら 3 品種は, 耐倒伏性が優れているので, 「あ きたこまち」や「ひとめぼれ」が倒伏するような多肥栽培や直播栽培においての多収が期待される.

キーワード：外観品質, 水稲, 食味, 収量, 窒素追肥.
\end{abstract}

近年, 東北地域の水稲栽培においては,「あきたこまち」 や「ひとめぼれ」など知名度の高い普及品種と比較して, 外観品質や食味は同等で, 収量が安定して高く, やや安值 でも取引できる中食・外食向けの品種の要望が高まってい る. そこで, 農研機構東北農業研究センター（以下, 東北 農研）では，「萌えみのり」(2006 年品種登録出願, 片岡ら 2007), 「えみのあき」（2013 年品種登録出願, 梶ら 2013),「ち ほみのり」（2014 年品種登録出願, 太田ら 2016）を育成し てきた。「萌えみのり」は中生の多収良食味品種である。「え みのあき」は，中生の良食味品種であり，「萌えみのり」と 比較して, 収量は劣るものの, いもち病圃場抵抗性と品質 に優れる。「ちほみのり」は早生の多収良食味品種で，「萌 えみのり」より早生の品種が要望される地域での普及が期 待されている。これら東北農研育成 3 品種は, 程が短く耐 倒伏性が優れることから，多肥栽培によって多収を目指す ことや直播栽培によって省力化・大規模化を目指すことに 適している. 今後, 東北農研育成 3 品種を, 多収・高品質
良食味品種として普及していくためには，その栽培特性を 明確にする必要がある。現在の東北地域の水稲栽培におい ては，「あきたこまち」，「ひとめぼれ」等の普及品種に適し た施肥等の栽培技術が確立されている。 これらの品種と比 較して, 東北農研育成 3 品種は, 生育特性が異なるため, 施肥の量や時期に対する反応性も異なっている可能性があ る。その中で, 本研究では, 慣行に近い施肥量の移植栽培 において追肥の時期が，東北農研育成 3 品種の生育・収量・ 品質・食味に及ぼす影響を明らかにしようとした。

\section{材料と方法}

本研究は, 2015 年に東北農研大仙拠点（秋田県大仙市） の水田圃場において実施した。まず，試験実施年の特徵を 明確とするため, 2000～2015 年について, 気象庁が公表し ている秋田県大仙市の気象データおよび東北農研大仙拠点 で実施した生産力検定試験・標肥移植栽培の結果をとりま とめた (第 1 表).

第 1 表 2000 年 2015 年における気象および水稲生産力検定試験の概況

\begin{tabular}{|c|c|c|c|c|c|c|c|c|c|c|}
\hline & \multicolumn{2}{|c|}{ 日照時間 } & h) & \multicolumn{3}{|c|}{ 平均気温 $\left({ }^{\circ} \mathrm{C}\right)$} & \multicolumn{2}{|c|}{ 出穂期（月／日） } & \multicolumn{2}{|c|}{ 精玄米重 $\left(\mathrm{g} / \mathrm{m}^{2}\right)$} \\
\hline & 6 月 & 7 月 & 8 月 & 6 月 & 7 月 & 8 月 & あきたこまち & ひとめぼれ & あきたこまち & ひとめぼれ \\
\hline 2015 年 & 194 & 181 & 158 & 19.8 & 23.6 & 24.0 & $7 / 30$ & $8 / 5$ & 641 & 683 \\
\hline 最小值 & 142 & 88 & 94 & 18.6 & 20.4 & 22.6 & $7 / 29$ & $8 / 3$ & 506 & 563 \\
\hline 平均值 & 183 & 143 & 178 & 19.9 & 23.1 & 24.4 & $8 / 2$ & $8 / 6$ & 595 & 640 \\
\hline 最大值 & 244 & 200 & 269 & 21.3 & 24.7 & 26.6 & $8 / 8$ & $8 / 11$ & 695 & 721 \\
\hline
\end{tabular}

最小值，平均值，最大值は 2000 年〜 2014 年の值，日照時間，平均気温は大仙市のアメダスデータ。出穂期，精玄米重は隣接する戋場で実施 した生産力検定試験・標肥移植栽培の結果. 耕種概要は福嶌ら（2015）を参照. 
早生品種群として,「ちほみのり」，および対照品種「あ きたこまち」，比較品種「まっしぐら」を用いた，中生品 種群として,「萌えみのり」,「えみのあき」, 対照品種「ひ とめぼれ」を用いた。いずれの品種群も, 固場を 3 つのブ ロックに分け, 各ブロックに 3 品種区 $\times 3$ 追肥区（無追 肥区, 前期追肥区, 後期追肥区）の計 9 処理区を配置した. ブロック内の試験区は，作業効率を考慮して配置したが, 完全無作為に配置したと仮定して, 3 反復の乱塊法で統計 処理を行った。

苗箱播種は 4 月 23 日, 移植は 5 月 21 日であった。栽植 様式は条間 $30 \mathrm{~cm}$, 株間 $15 \mathrm{~cm}, 1$ 株 3 本の手植えとした。 試験区面積は 4 条 $\times 4 \mathrm{~m}\left(4.8 \mathrm{~m}^{2}\right)$ とした，施肥法は，実 際の生産者の栽培方法に近く, かつ, 追肥の効果が明確と なることを考慮して, 基肥は, 化成肥料を用いて窒素 4 $\mathrm{kg} / 10 \mathrm{a}$, リン酸 $4 \mathrm{~kg} / 10 \mathrm{a}$, カリ $4 \mathrm{~kg} / 10 \mathrm{a}$, 追肥は, 硫安を 用いた窒素 $3 \mathrm{~kg} / 10 \mathrm{a}$ とした。追肥時期は, いずれの品種群 も，前期追肥区 7 月 6 日，後期追肥区 7 月 20 日とした。

7 月以降, 1 週間に 1 回の割合で葉緑素計（コニカミノル 夕社，SPAD502）を用いて葉色（SPAD）值を測定した。測 定部位は, 抽出中の葉から 2 枚下の葉の中央部とし, 穂揃期 以降は止葉の中央部とし, 試験区当たり 10 葉を測定した. 出穂 $1 \sim 2$ 週間後に, 試験区当たり 2 株を採種し, 1 株を 3 分し, その中で 2 番目に稈の長い穂・茎葉, 合計 6 本につい て, 穂および茎葉の形態的諸形質を測定した，成熟期に試験 区当たり 40 株を収穫し, 収量関連形質・品質・食味を調査 した。笠は $1.8 \mathrm{~mm}$ で行い, 収量・収量構成要素は均分法 により求めた（楠田 1995），精玄米の蛋白質含量（以下，玄 米蛋白質) は, 近赤外分光分析装置（FOSS 社 infratec1214） を用いて測定した. 収量, 千粒重, 玄米蛋白質は水分 $15 \%$ に換算した值を示した，玄米の外観品質は，井上（1996）を 参考にして, 目視で評価した. 食味官能試験は, 福井・小林 （1996）を参考にして，東北農研職員により実施した。

\section{結果}

\section{1. 気象および生産力検定試験の概況}

2015 年の日照時間は, 6 月で平年並, 7 月でやや長く, 8 月でやや短かった (第 1 表)。平均気温は, 6 月で平年並, 7 月でやや高く, 8 月でやや低かった. 出穂期は, 早生の「あ きたこまち」で早まり, 中生の「ひとめぼれ」で平年並で あった。精玄米重は，「あきたこまち」，「ひとめぼれ」と もに平年よりも多かった，2015 年の生産力検定試験の結果 は, 隣接する圃場で実施した本研究の結果と大きく異なる ことはなかった。

\section{2. 葉色値の推移}

早生品種群の中では,「あきたこまち」は,「まっしぐら」, 「ちほみのり」と比較して, 出穂前の 7 月 20 日までの葉色 值が高い傾向にあったが, それ以降, 品種間差異は認めら れなかった (第 1 図). 追肥を行うと葉色值は高くなり，
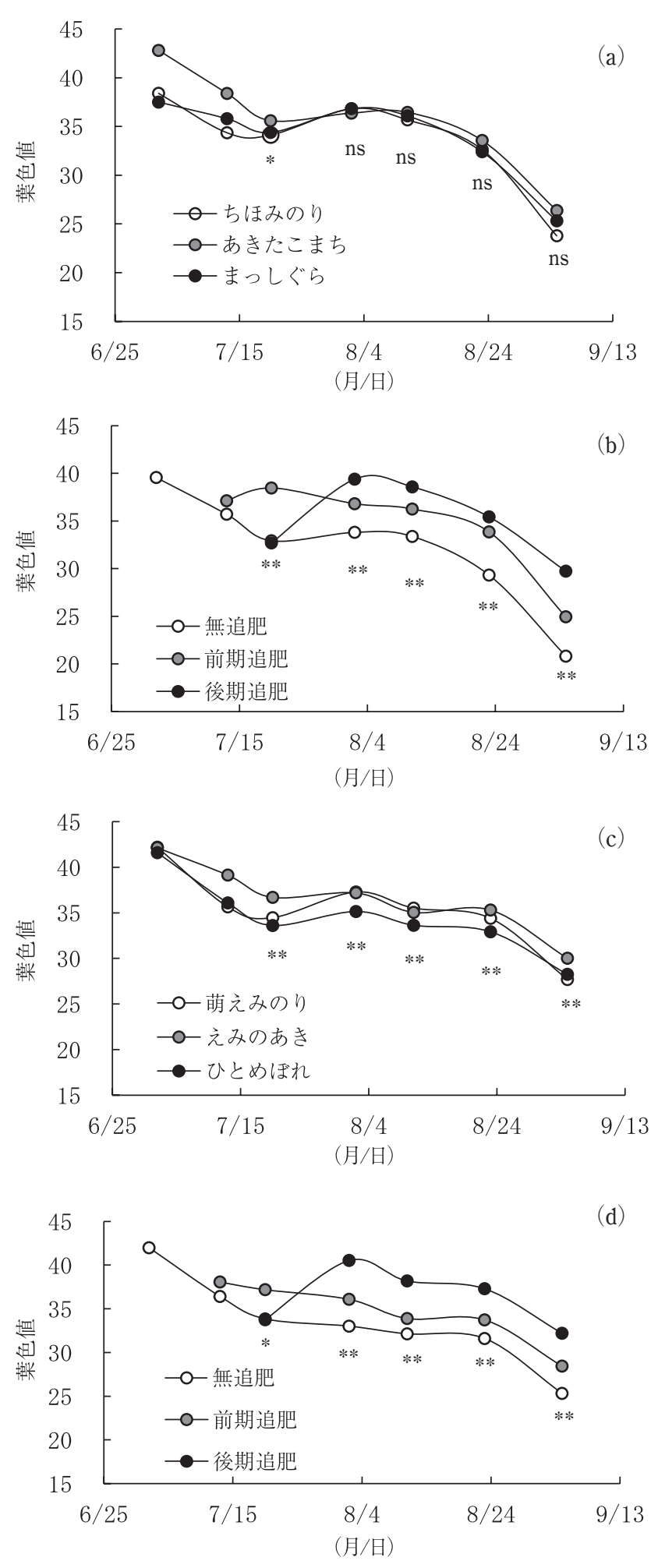

第 1 図 水稲品種における葉色值の推移.

(a) 早生品種群における品種間差異. (b) 早生品種群におけ る追肥法間差異. (c) 中生品種群における品種間差異. (d) 中生品種群における追肥法間差異. **, *, ns は, 分散分析 に拉いて， $1 \%$ 水準， $5 \%$ 水準で有意であること，有意でない ことを示す， 7 月 2 日， 7 月 13 日は反復数が不足していたた め統計処理を実施しなかった. 
第 2 表 東北農研が育成した水稲品種における穂の形態的形質の品種間差異および追肥法間差異

\begin{tabular}{|c|c|c|c|c|c|c|c|c|c|c|}
\hline & & $\begin{array}{c}1 \text { 次 } \\
\text { 枝梗数 }\end{array}$ & $\begin{array}{l}1 \text { 次 } \\
\text { 籵数 }\end{array}$ & $\begin{array}{l}2 \text { 次 } \\
\text { 籾数 }\end{array}$ & $\begin{array}{c}1 \text { 穂分化 } \\
\text { 籾数 }\end{array}$ & $\begin{array}{c}1 \text { 穂退化 } \\
\text { 籾数 }\end{array}$ & $\begin{array}{c}1 \text { 穂生存 } \\
\text { 籾数 }\end{array}$ & 2 次籾率 & $\begin{array}{l}\text { 穂長 } \\
(\mathrm{cm})\end{array}$ & $\begin{array}{c}\text { 粒着密度 } \\
(/ \mathrm{cm})\end{array}$ \\
\hline \multirow{11}{*}{ 早生品種群 } & ちほみのり & 7.5 & 40.9 & 32.5 & 87.2 & 13.7 & 73.4 & 0.44 & 16.6 & 4.43 \\
\hline & あきたこまち & 8.9 & 48.0 & 29.1 & 92.0 & 14.8 & 77.2 & 0.38 & 15.9 & 4.86 \\
\hline & まっしぐら & 8.1 & 45.5 & 35.0 & 98.0 & 17.5 & 80.5 & 0.43 & 16.8 & 4.80 \\
\hline & 無追肥 & 7.9 & 43.4 & 30.7 & 88.8 & 14.7 & 74.1 & 0.41 & 16.2 & 4.57 \\
\hline & 前期追肥 & 8.1 & 44.7 & 33.7 & 93.0 & 14.6 & 78.4 & 0.43 & 16.7 & 4.69 \\
\hline & 後期追肥 & 8.4 & 46.3 & 32.3 & 95.4 & 16.8 & 78.6 & 0.41 & 16.3 & 4.83 \\
\hline & 品種 & $* *$ & $* *$ & * & * & $* *$ & ns & $* *$ & $* *$ & * \\
\hline & LSD (5\%) & 0.5 & 2.8 & 4.5 & 7.1 & 2.3 & 6.5 & 0.0 & 0.5 & 0.3 \\
\hline & 追肥法 & ns & ns & ns & ns & ns & ns & ns & ns & ns \\
\hline & LSD (5\%) & 0.5 & 2.8 & 4.5 & 7.1 & 2.3 & 6.5 & 0.0 & 0.5 & 0.3 \\
\hline & 交互作用 & ns & ns & ns & ns & ns & ns & ns & ns & ns \\
\hline \multirow{11}{*}{ 中生品種群 } & 萌えみのり & 7.9 & 43.6 & 33.0 & 91.7 & 15.2 & 76.5 & 0.43 & 18.4 & 4.17 \\
\hline & えみのあき & 8.4 & 47.1 & 22.3 & 81.9 & 12.6 & 69.3 & 0.32 & 19.2 & 3.61 \\
\hline & ひとめぼれ & 8.1 & 44.5 & 25.3 & 80.7 & 10.9 & 69.8 & 0.36 & 18.6 & 3.76 \\
\hline & 無追肥 & 8.2 & 45.4 & 26.0 & 86.4 & 15.0 & 71.4 & 0.36 & 18.1 & 3.95 \\
\hline & 前期追肥 & 7.9 & 44.3 & 27.0 & 85.3 & 14.0 & 71.2 & 0.38 & 18.6 & 3.83 \\
\hline & 後期追肥 & 8.2 & 45.5 & 27.5 & 82.7 & 9.7 & 73.0 & 0.37 & 19.4 & 3.76 \\
\hline & 品種 & ns & * & $* *$ & $* *$ & $* *$ & * & $* *$ & $* *$ & $* *$ \\
\hline & LSD $(5 \%)$ & 0.4 & 2.3 & 3.3 & 6.2 & 2.2 & 5.1 & 0.0 & 0.5 & 0.2 \\
\hline & 追肥法 & ns & ns & ns & ns & $* *$ & ns & ns & $* *$ & ns \\
\hline & LSD (5\%) & 0.4 & 2.3 & 3.3 & 6.2 & 2.2 & 5.1 & 0.0 & 0.5 & 0.2 \\
\hline & 交互作用 & ns & ns & ns & ns & ns & ns & ns & ns & ns \\
\hline
\end{tabular}

1 穂分化籾数 -1 穂退化籾数 $=1$ 穂生存籾数, 2 次籾率 $=2$ 次籾数 $/ 1$ 穂生存籾数, 粒着密度 $=1$ 穂生存籾数 $/$ 穂長. **, * ns は, 分散分析 において，1\%水準，5\%水準で有意であること，有意でないことを示す，LSD (5\%) は，5\%水準の最小有意差を示す.

出穂期以降の葉色值は, 後期追肥区, 前期追肥区, 無追肥 区の順に高かった.

中生品種群の中では,「萌えみのり」は, 8 月 2 日〜 23 日の間は「えみのあき」程度に葉色值が高く, その前後は 「ひとめぼれ」程度に葉色值が低かった。「えみのあき」は 「ひとめぼれ」よりも，7月 20 日〜9月 4 日までの間，葉 色值が高かった，追肥を行うと葉色值は高くなり，出穂期 以降の葉色值は, 後期追肥区, 前期追肥区, 無追肥区の順 に高かった。

\section{3. 穂および茎・葉の形態特性}

\section{(1) 早生品種群}

穂に関する形質については, 品種間差異は認められるこ とが多かったが, 追肥法間の差異は認められなかった（第 2 表)。すなわち,「まっしぐら」は,「ちほみのり」,「あき たこまち」と比較して，1穂分化籾数が多いが， 1 穂退化 籾数も多いため, 1 穂生存籾数に大きな品種間差異は認め られなかった１次枝梗数は，「あきたこまち」，「まっしぐ ら」,「ちほみのり」の順に多く, 2 次籾率は, 「まっしぐら」, 「ちほみのり」が「あきたこまち」より高かった，穂長は， 「あきたこまち」が「まっしぐら」,「ちほみのり」より短く， 粒着密度は,「ちほみのり」が「まっしぐら」,「あきたこ
まち」よりやや低かった.

秙長は,「あきたこまち」,「まっしぐら」,「ちほみのり」 の順に長く, 前期追肥区, 後期追肥区が, 無追肥区より長 かった (第 3 表)，穂抽出程度は，「まっしぐら」，「あきた こまち」,「ちほみのり」の順に大きく, 追肥法間の差異は 認められなかった。葉身長は,「まっしぐら」が「ちほみ のり」,「あきたこまち」より長く, 追肥法間の差異は認め られなかった、葉身幅は，「あきたこまち」が，「まっしぐ ら」,「ちほみのり」より広く, 前期追肥区が, 無追肥区, 後期追肥区より広かった。節間長比は,「まっしぐら」,「ち ほみのり」が「あきたこまち」より高く, 追肥法間の差異 は認められなかった。節間直径は, 品種間および追肥法間 の差異は認められなかった。

\section{（2）中生品種群}

穂に関する形質については,「萌えみのり」は「ひとめ ぼれ」,「えみのあき」より 1 穂分化籾数が多く, 1 穂生存 籾数も多かった (第 2 表)。これは 2 次籾率が高く, 2 次 籾数が多いためであった，穂長は，「えみのあき」が「ひ とめぼれ」,「萌えみのり」より長く, 粒着密度は, 「萌え みのり」が「ひとめぼれ」,「えみのあき」より高かった。 追肥法に関しては, 後期追肥によって退化籾数が減少し, 穂長は後期追肥区，前期追肥区，無追肥区の順に長くなっ 
第 3 表 東北農研が育成した水稲品種における茎葉の形態的形質の品種間差異および追肥法間差異.

\begin{tabular}{|c|c|c|c|c|c|c|c|c|}
\hline & & $\begin{array}{l}\text { 稈長 } \\
(\mathrm{cm}) \\
\end{array}$ & $\begin{array}{c}\text { 穂抽出程度 } \\
(\mathrm{cm})\end{array}$ & $\begin{array}{c}\text { 葉身長 } \\
(\mathrm{cm})\end{array}$ & $\begin{array}{c}\text { 葉身幅 } \\
(\mathrm{cm})\end{array}$ & $\begin{array}{c}\text { 葉鞘長 } \\
(\mathrm{cm})\end{array}$ & $\begin{array}{c}\text { 節間直径 } \\
(\mathrm{mm})\end{array}$ & 節間長比 \\
\hline \multirow{11}{*}{ 早生品種群 } & ちほみのり & 72.2 & 5.09 & 27.9 & 0.98 & 21.5 & 2.94 & 0.88 \\
\hline & あきたこまち & 81.7 & 5.83 & 27.6 & 1.04 & 21.9 & 2.93 & 0.82 \\
\hline & まっしぐら & 77.5 & 6.98 & 29.5 & 1.00 & 22.2 & 3.06 & 0.88 \\
\hline & 無追肥 & 74.5 & 5.69 & 28.0 & 0.99 & 21.6 & 3.01 & 0.87 \\
\hline & 前期追肥 & 78.9 & 6.31 & 29.2 & 1.04 & 22.1 & 2.98 & 0.86 \\
\hline & 後期追肥 & 78.0 & 5.91 & 27.9 & 1.00 & 21.8 & 2.95 & 0.85 \\
\hline & 品種 & $* *$ & $* *$ & $* *$ & $* *$ & $*$ & ns & $* *$ \\
\hline & LSD (5\%) & 1.8 & 0.8 & 1.2 & 0.03 & 0.5 & 0.2 & 0.02 \\
\hline & 追肥法 & $* *$ & ns & ns & $* *$ & ns & ns & NS \\
\hline & LSD (5\%) & 1.8 & 0.8 & 1.2 & 0.03 & 0.5 & 0.2 & 0.02 \\
\hline & 交互作用 & ns & ns & ns & ns & ns & ns & ns \\
\hline \multirow{11}{*}{ 中生品種群 } & 萌えみのり & 67.7 & 5.86 & 27.9 & 1.02 & 21.4 & 2.98 & 0.88 \\
\hline & えみのあき & 62.8 & 4.67 & 30.0 & 1.04 & 23.2 & 2.94 & 0.88 \\
\hline & ひとめぼれ & 79.0 & 9.39 & 30.3 & 0.98 & 22.1 & 2.92 & 0.87 \\
\hline & 無追肥 & 69.4 & 6.56 & 29.6 & 1.01 & 22.0 & 2.98 & 0.87 \\
\hline & 前期追肥 & 70.2 & 6.96 & 30.1 & 1.05 & 22.3 & 2.97 & 0.88 \\
\hline & 後期追肥 & 69.9 & 6.39 & 28.5 & 0.97 & 22.4 & 2.89 & 0.88 \\
\hline & 品種 & $* *$ & $* *$ & $* *$ & ns & $* *$ & ns & $*$ \\
\hline & LSD (5\%) & 1.4 & 0.9 & 1.5 & 0.1 & 0.6 & 0.2 & 0.01 \\
\hline & 追肥法 & ns & ns & ns & ns & ns & ns & $*$ \\
\hline & LSD (5\%) & 1.4 & 0.9 & 1.5 & 0.1 & 0.6 & 0.2 & 0.01 \\
\hline & 交互作用 & ns & ns & ns & ns & ns & ns & $*$ \\
\hline
\end{tabular}

穂抽出程度は穂首節間〜第 I 葉葉関節までの長さ, 葉身長, 葉身幅, 葉鞘長は第 I 葉 (止葉) 〜第正葉の平均值, 節間直径は第

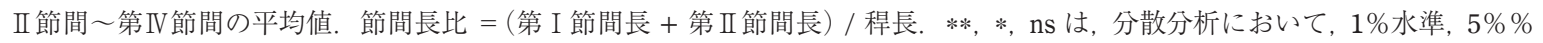
水準で有意であること，有意でないことを示す，LSD (5\%)は，5\%\%水準の最小有意差を示す.

たが，それ以外は追肥法間の差異は認められなかった

稈長扮よび穂抽出程度は,「ひとめぼれ」,「萌えみのり」, 「えみのあき」の順に長く, 追肥法間の差異は認められな かった (第 3 表)、葉身長は,「ひとめぼれ」,「えみのあき」 が「萌えみのり」より長く, 追肥法間の差異は認められな かった，葉身幅は，品種間㧍よび追肥法間の差異は認めら れなかった，節間長比は,「えみのあき」,「萌えみのり」,「ひ とめぼれ」の順に高く, 追肥法間の差異は認められなかっ た，節間直径は，品種間および追肥法間の差異は認められ なかった。

早生品種群, 中生品種群を通じてみると, 早生品種群は 中生品種群と比較して, 1 次枝梗数, 1 次籾数は同等であ るが， 2 次籾数が多いために， 1 穂生存籾数が多く，また， 穂長が短いこともあり粒着密度が高い傾向にあった．第 3 表には省略したが, 第 I 葉身長（止葉長）が，早生品種群 は平均 $20.3 \mathrm{~cm}$ と, 中生品種群の平均 $24.5 \mathrm{~cm}$ より明ら かに短かった。

\section{4. 収量 - 収量関連形質}

\section{(1) 早生品種群}

出穂期は,「まっしぐら」が 7 月 27 日,「ちほみのり」
が 7 月 27 日，「あきたこまち」が 7 月 29 日であり，追肥 法による差異は認められなかった (第 4 表)。穂数は,「ち ほみのり」が「あきたこまち」よりやや多く,「まっしぐら」 が最も少なかった．また，前期追肥区が，無追肥区，後期 追肥区より多かった１穂籾数は，「まっしぐら」が「ちほ みのり」,「あきたこまち」よりやや多く, 追肥法による差 異は認められなかった. その結果, 総籾数は品種間による 差異は認められず，前期追肥区が，無追肥区，後期追肥区 より多かった。千粒重は,「まっしぐら」,「ちほみのり」,「あ きたこまち」の順に大きく，後期追肥区が，無追肥区，前 期追肥区より大きかった。登熟歩合は品種間による差異は 求められず, 無追肥区, 後期追肥区が前期追肥区より高かっ た。その結果, 精玄米重は品種間による差異は認められず, 前期追肥区, 後期追肥区, 無追肥区の順に多かった。屑米 重は,「あきたこまち」,「ちほみのり」,「まっしぐら」の 順にやや多く，前期追肥区が，無追肥区，後期追肥区より 多かった，風乾全重は，品種間による差異は認められず, 前期追肥区，後期追肥区，無追肥区の順にやや多かった. 籾䕗比は,「ちほみのり」,「まっしぐら」,「あきたこまち」 の順に高く, 前期追肥区, 無追肥区, 後期追肥区の順に高 かった。倒伏程度に関しては,「あきたこまち」において 
第 4 表 東北農研が育成した水稲品種における収量・品質関連形質の品種間差異および追肥法間差異

\begin{tabular}{|c|c|c|c|c|c|c|c|c|c|c|c|c|c|c|c|}
\hline & 出穗期 & 穂数 & \multirow{2}{*}{1 穂籾数 } & \multirow{2}{*}{$\begin{array}{c}\text { 総籾数 } \\
\left(/ \mathrm{m}^{2}\right)\end{array}$} & \multirow{2}{*}{$\begin{array}{c}\text { 千粒重 } \\
\text { (g) }\end{array}$} & \multirow{2}{*}{\multicolumn{2}{|c|}{$\begin{array}{c}\text { 登熟歩合 精玄米重 } \\
(\%) \quad\left(\mathrm{g} / \mathrm{m}^{2}\right)\end{array}$}} & \multirow{2}{*}{$\begin{array}{l}\text { 屑米重 } \\
\left(\mathrm{g} / \mathrm{m}^{2}\right)\end{array}$} & \multirow{2}{*}{$\begin{array}{c}\text { 風乾全重 } \\
\left(\mathrm{g} / \mathrm{m}^{2}\right)\end{array}$} & \multirow{2}{*}{$\begin{array}{c}\text { 籾萻比 } \\
(\%)\end{array}$} & \multirow{2}{*}{$\begin{array}{c}\text { 倒伏程度 } \\
(0-5)\end{array}$} & \multicolumn{2}{|c|}{ 外観品質 } & \multirow{2}{*}{$\begin{array}{c}\text { 玄米蛋白質 } \\
(\%)\end{array}$} \\
\hline & & (月/日) & $\left(/ \mathrm{m}^{2}\right)$ & & & & & & & & & & 総合 & 乳白粒 & \\
\hline \multirow{11}{*}{ 早生品種群 } & ちほみのり & $7 / 27$ & 512 & 60 & 30783 & 23.3 & 91.3 & 652 & 10.4 & 1534 & 106 & 0.0 & 3.8 & 0.4 & 7.2 \\
\hline & あきたこまち & $7 / 29$ & 485 & 63 & 30500 & 22.8 & 90.6 & 629 & 13.9 & 1573 & 96 & 0.5 & 3.3 & 0.2 & 7.4 \\
\hline & まっしぐら & $7 / 27$ & 442 & 67 & 29585 & 23.7 & 92.0 & 643 & 8.1 & 1557 & 99 & 0.0 & 3.9 & 0.7 & 7.2 \\
\hline & 無追肥 & $7 / 28$ & 443 & 63 & 27710 & 23.1 & 92.4 & 590 & 7.0 & 1433 & 100 & 0.1 & 3.7 & 0.2 & 6.7 \\
\hline & 前期追肥 & $7 / 28$ & 534 & 64 & 34201 & 23.0 & 88.9 & 698 & 17.4 & 1655 & 106 & 0.3 & 3.9 & 1.0 & 7.1 \\
\hline & 後期追肥 & $7 / 27$ & 463 & 63 & 28957 & 23.8 & 92.6 & 636 & 8.1 & 1576 & 95 & 0.1 & 3.4 & 0.1 & 8.0 \\
\hline & 品種 & $* *$ & $* *$ & $*$ & ns & $* *$ & ns & ns & * & ns & $* *$ & $* *$ & $* *$ & ns & ns \\
\hline & LSD $(5 \%)$ & 0.6 & 41 & 4 & 2060 & 0.3 & 2.8 & 28.1 & 3.8 & 73 & 3 & 0.3 & 0.2 & 0.5 & 0.3 \\
\hline & 追肥法 & ns & $* *$ & ns & $* *$ & $* *$ & $*$ & $* *$ & $* *$ & $* *$ & $* *$ & ns & $* *$ & $* *$ & $* *$ \\
\hline & LSD $(5 \%)$ & 0.6 & 41 & 4 & 2060 & 0.3 & 2.8 & 28.1 & 3.8 & 73 & 3 & 0.3 & 0.2 & 0.5 & 0.3 \\
\hline & 交互作用 & ns & ns & ns & ns & ns & ns & ns & ns & ns & $* *$ & ns & $\mathrm{ns}$ & ns & ns \\
\hline \multirow{11}{*}{ 中生品種群 } & 萌えみのり & $8 / 1$ & 499 & 65 & 32095 & 24.9 & 88.1 & 700 & 17.1 & 1513 & 129 & 0.0 & 4.3 & 1.0 & 6.5 \\
\hline & えみのあき & $8 / 4$ & 520 & 57 & 29425 & 24.3 & 88.5 & 631 & 18.3 & 1645 & 89 & 0.0 & 3.5 & 0.8 & 6.8 \\
\hline & ひとめぼれ & $8 / 2$ & 526 & 61 & 31996 & 24.3 & 87.0 & 674 & 20.1 & 1561 & 115 & 0.8 & 4.1 & 0.9 & 6.5 \\
\hline & 無追肥 & $8 / 2$ & 486 & 58 & 28224 & 24.3 & 89.9 & 616 & 14.7 & 1469 & 107 & 0.2 & 3.9 & 0.6 & 6.2 \\
\hline & 前期追肥 & $8 / 3$ & 564 & 60 & 33731 & 23.8 & 85.7 & 687 & 23.5 & 1678 & 103 & 0.3 & 4.1 & 1.4 & 6.5 \\
\hline & 後期追肥 & $8 / 2$ & 494 & 65 & 31559 & 25.3 & 88.0 & 703 & 17.3 & 1572 & 123 & 0.4 & 3.9 & 0.7 & 7.2 \\
\hline & 品種 & $* *$ & ns & * & * & $* *$ & ns & $* *$ & ns & $* *$ & $* *$ & $* *$ & $* *$ & ns & * \\
\hline & LSD $(5 \%)$ & 0.5 & 31.8 & 5.5 & 1844 & 0.2 & 3.9 & 22.0 & 3.3 & 46.0 & 4.4 & 0.1 & 0.3 & 0.7 & 0.2 \\
\hline & 追肥法 & ns & $* *$ & ns & $* *$ & $* *$ & ns & $* *$ & $* *$ & $* *$ & $* *$ & * & $\mathrm{ns}$ & $*$ & $* *$ \\
\hline & LSD $(5 \%)$ & 0.5 & 31.8 & 5.5 & 1844 & 0.2 & 3.9 & 22.0 & 3.3 & 46.0 & 4.4 & 0.1 & 0.3 & 0.7 & 0.2 \\
\hline & 交互作用 & ns & ns & ns & ns & ns & ns & ns & ns & ns & ns & $* *$ & $\mathrm{~ns}$ & ns & ns \\
\hline
\end{tabular}

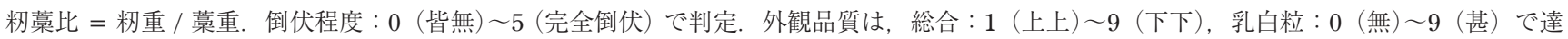
観により判定．**，*， ns は，分散分析において，1\%水準，5\%水準で有意であること，有意でないことを示す，LSD（5\%）は，5\%水準の 最小有意差を示す。

のみ，なびく程度の倒伏が認められ，その程度は，前期追 肥区が，後期追肥区，無追肥区より大きかった。

\section{（2）中生品種群}

出穂期は，「ひとめぼれ」が 8 月 2 日，「萌えみのり」が 8 月 1 日，「えみのあき」が 8 月 4 日であり，追肥法によ る差異は認められなかった（第 4 表）。穂数は，品種間に よる差異は認められず，前期追肥区が，無追肥区，後期追 肥区より多かった。1 穂籾数は，「萌えみのり」「「とめぼ れ」，「えみのあき」の順に多い傾向が認められ，追肥法間 による差異は認められなかった。その結果, 総籾数は,「ひ とめほれ」，「萌えみのり」が「えみのあき」より多く，前 期追肥区，後期追肥区，無追肥区の順に多かった。千粒重 は，「萌えみのり」が「ひとめぼれ」，「えみのあき」より 重く，後期追肥区，無追肥区，前期追肥区の順に重かった. 登熟歩合は，品種間や追肥法間による差異が認められな かった。その結果，精玄米重は，「萌えみのり」，「ひとめ ぼれ」，「えみのあき」の順に多く，前期追肥区，後期追肥 区が無追肥区より多かった。屑米重は，品種間による差異 は認められず，前期追肥区，後期追肥区，無追肥区の順に 多かった。風乾全重は，「えみのあき」，「ひとめぼれ」，「萌 えみのり」の順に大きく，籾葈比は，「萌えみのり」，「ひ
とめぼれ」「「えみのあき」の順に高く，後期追肥区が，無 追肥区, 前期追肥区より高かった。倒伏程度に関しては,「ひ とめぼれ」においてのみ, なびく程度の倒伏が認められ, その程度は，前期追肥区，後期追肥区が，無追肥区より大 きかった。

\section{5. 品質 · 食味}

外観品質の総合值は, 3.4 4.3の範囲であり, 品種, 追肥法によらず良好であった（第 4 表），その範囲内の差 異をみると, 早生品種群の中では「あきたこまち」, 中生 品種群の中では「えみのあき」が優れており，また，早生 品種群の中では後期追肥区が優れており, 中生品種群の中 では追肥法による差異が認められなかった。総合值が劣る 場合は，乳白粒の発生が多い傾向にあった。乳白粒の発生 は, いずれの品種群においても, 品種間差異は認められず, 前期追肥区において多かった。 心白粒，背白・基白粒の発 生は, いずれの品種群においても僅かであったので表記を 省略した。立米蛋白質は, いずれの品種群においても, 後 期追肥区，前期追肥区，無追肥区の順に高かった。早生品 種群においては，玄米蛋白質に品種間差異は認められず, 中生品種群の中では,「えみのあき」の玄米蛋白質がやや 
第 5 表 東北農研が育成した水稲品種の食味官能試験における品種間差異および追肥法間差異.

\begin{tabular}{|c|c|c|c|c|c|c|c|c|c|c|c|c|c|}
\hline \multirow{2}{*}{ 試験番号 } & \multirow{2}{*}{ 品種 } & \multirow{2}{*}{ 追肥法 } & \multirow{2}{*}{$\begin{array}{c}\text { 搗精歩合 } \\
(\%)\end{array}$} & \multirow{2}{*}{$\begin{array}{c}\text { 砕米率 } \\
(\%)\end{array}$} & \multirow{2}{*}{ 精米白度 } & \multirow{2}{*}{$\begin{array}{c}\text { 白米水分 } \\
(\%)\end{array}$} & \multicolumn{5}{|c|}{ 評価 $(-3 \sim+3)$} & \multicolumn{2}{|c|}{ 総合值の有意差 } \\
\hline & & & & & & & 光沢 & 味 & 粘り & 硬さ & 総合值 & 1 回目 & 2 回目 \\
\hline \multirow{6}{*}{ 試験 1} & \multirow{3}{*}{ あきたこまち } & 無追肥区 & 88.1 & 0.97 & 45.4 & 13.2 & 0.00 & 0.00 & 0.00 & 0.00 & 0.00 & & \\
\hline & & 前期追肥区 & 88.4 & 0.50 & 45.2 & 13.0 & -0.12 & -0.16 & -0.28 & 0.16 & -0.20 & ns & ns \\
\hline & & 後期追肥区 & 89.0 & 0.43 & 43.5 & 13.0 & -0.20 & -0.28 & -0.47 & 0.21 & -0.44 & $*$ & ns \\
\hline & \multirow{3}{*}{ ちほみのり } & 無追肥区 & 88.8 & 0.44 & 46.1 & 13.0 & -0.05 & -0.05 & -0.12 & -0.20 & -0.13 & ns & ns \\
\hline & & 前期追肥区 & 88.8 & 0.33 & 45.2 & 13.0 & 0.00 & 0.05 & -0.15 & -0.05 & 0.00 & ns & ns \\
\hline & & 後期追肥区 & 88.9 & 0.37 & 44.6 & 13.1 & -0.04 & -0.41 & -0.56 & 0.04 & -0.60 & $* *$ & $* *$ \\
\hline \multirow{6}{*}{ 試験 2} & \multirow{3}{*}{ ひとめぼれ } & 無追肥 & 88.7 & 0.54 & 44.9 & 13.5 & 0.00 & 0.00 & 0.00 & 0.00 & 0.00 & & \\
\hline & & 前期追肥 & 89.1 & 0.65 & 45.1 & 13.2 & -0.04 & -0.03 & -0.10 & -0.15 & -0.13 & ns & ns \\
\hline & & 後期追肥 & 88.9 & 0.65 & 45.0 & 13.2 & -0.18 & -0.21 & -0.31 & 0.02 & -0.46 & ns & $*$ \\
\hline & \multirow{3}{*}{ 萌えみのり } & 無追肥 & 88.9 & 0.48 & 46.1 & 13.1 & -0.15 & 0.04 & -0.13 & -0.28 & -0.10 & ns & ns \\
\hline & & 前期追肥 & 88.4 & 0.61 & 47.1 & 12.8 & -0.36 & -0.24 & -0.32 & -0.49 & -0.57 & $* *$ & ns \\
\hline & & 後期追肥 & 89.1 & 0.55 & 44.8 & 12.8 & -0.18 & -0.33 & -0.45 & -0.13 & -0.38 & $*$ & ns \\
\hline \multirow{9}{*}{ 試験 3} & \multirow{3}{*}{ ひとめぼれ } & 無追肥 & 88.9 & 0.71 & 45.6 & 13.3 & 0.00 & 0.00 & 0.00 & 0.00 & 0.00 & & \\
\hline & & 前期追肥 & 89.5 & 0.77 & 45.5 & 13.0 & -0.14 & 0.01 & -0.05 & 0.05 & -0.13 & ns & ns \\
\hline & & 後期追肥 & 88.8 & 0.64 & 44.9 & 12.9 & -0.19 & -0.25 & -0.48 & 0.09 & -0.48 & $\mathrm{~ns}$ & $* *$ \\
\hline & \multirow{3}{*}{ えみのあき } & 無追肥 & 84.1 & 1.14 & 47.2 & 13.1 & -0.20 & -0.20 & -0.26 & -0.35 & -0.30 & ns & $*$ \\
\hline & & 前期追肥 & 87.5 & 0.70 & 44.9 & 13.0 & -0.10 & -0.07 & 0.09 & -0.39 & -0.15 & ns & ns \\
\hline & & 後期追肥 & 85.9 & 0.98 & 44.8 & 13.1 & -0.14 & -0.38 & -0.38 & -0.05 & -0.47 & $*$ & ns \\
\hline & \multirow{3}{*}{ 平均値 } & 無追肥区 & 87.9 & 0.71 & 45.8 & 13.2 & -0.07 & -0.03 & -0.08 & -0.14 & -0.09 & & \\
\hline & & 前期追肥区 & 88.6 & 0.59 & 45.5 & 13.0 & -0.12 & -0.07 & -0.13 & -0.15 & -0.20 & & \\
\hline & & 後期追肥区 & 88.4 & 0.60 & 44.6 & 13.0 & -0.15 & -0.31 & -0.44 & 0.03 & -0.47 & & \\
\hline
\end{tabular}

あきたこまち・無追肥区を基準とした試験 1 ，ひとめぼれ・無追肥区を基準とした試験 2 ，試験 3 を各 2 回実施し，その平均值を示した。パ ネル数は 9 人〜 13 人であった。炊飯白米量 $400 \mathrm{~g}$, 加水量 1.35 (白米重量比) とした。総合值の有意差における**, $* \mathrm{~ns}$ は, $\mathrm{t}$ 検定に扔いて, $1 \%$ 水準, $5 \%$ 水準で有意であること, 有意でないことを示す.

高かった.

食味官能試験に関して, 総合值は, 品種間差異はほとん ど認められず，無追肥区より追肥区でやや低く，特に後期 追肥区で低い傾向が認められた（第 5 表）。後期追肥区は, 無追肥区や前期追肥区と比較して, 味が不良で, 粘りが弱 く, 硬いと判断される傾向にあった。

\section{考察}

水稲の追肥に対する反応性に関しては, 古くから基礎試 験が数多く実施されており（松島 1977）, 生産現場に近い 応用試験も数多く実施されている。 これら従来の知見と本 研究の結果は概ね一致すると推察されたが, 栽培条件や品 種によって異なる部分もあると考えられる。本研究では, 様々な形質を調査したが, 品種・追肥法の交互作用に有意 差はほとんど認められなかったことから（第 2 表, 第 3 表, 第 4 表), 東北農研育成 3 品種は, 追肥に対して特異的な 反応を示すことはないと推察される。 そこで, 早生品種群 および中生品種群の追肥に対する反応性, および, 東北農 研育成品種の追肥法によらない特性という視点から考察し たい。なお，本研究は，2015年のみの実施であったが， 2015 年は, 平年と比較して, 多収であったものの, 気象㧍 よび収量が極端に異なることはなかったので（第 1 表）,
特殊な条件における結果ではないと判断される.

東北地域に扔ける窒素施肥量は, 基肥 $5 \mathrm{~kg} / 10 \mathrm{a}$, 出穂 25 〜20 日前の追肥 $2 \mathrm{~kg} / 10 \mathrm{a}$ 一般的である. 近年では, これ らの施肥法と同等の効果が期待できる遅効性肥料を含んだ 基肥のみを施用する場合も増えている. 本研究では, 早生 品種群の前期追肥が出穂 22 日前, 後期追肥が出穗 8 日前, 中生品種群の前期追肥が出穗 28 日前, 後期追肥が出穂 14 日前におよそ相当した。

葉色値は, 両品種群ともに, 追肥 1 週間以降は高く維持 されていることから, 追肥の効果は明確に現れていると判 断される (第 1 図 b, d ). 東北農研育成品種の葉色值につい てみると,「ちほみのり」は「あきたこまち」より出穂前 の葉色值が低く(第 1 図a),「萌えみのり」,「えみのあき」 は「ひとめぼれ」より登熟期間の葉色值が高かった（第 1 図 c)。このような葉色值の品種特性は, 東北農研育成品種 の普及にあたって肥培管理の混乱を招く危険性があるの で，生産者に説明しておく必要がある。

穂および茎葉の形態的形質に関しては, 追肥法による差 異が認められることは少なかった（第 2 表，第 3 表）。福 嶌 (2007) は, 葉および穂の形態特性は, それらの形質が 決まる時期の窒素追肥の影響を強く受けることを認めてい る. これに対して, 本研究における追肥時期は出穗 28 日 
以降と穂・茎葉の形態がほぼ決まる時期以降であったため に，穂・茥葉の形態的形質に及ぼす影響が少なかったと考 えられる，東北農研育成品種の形態的特徵については，育 成時に稈長・穂長が調査されてきたが，細部の特徵は不明 であった，稈長の品種間差異に関しては，育成時の結果と ほぼ一致していたが，穂長の品種間差異に関しては，「あ きたこまち」の穂長が短いことなど育成時の結果（梶ら 2013，太田ら 2016）とやや異なっていた。 よって，穂長お よび粒着密度の品種間差異に関しては, 再検討の必要があ る。さらに，本研究により，「ちほみのり」は「あきたこ まち」と比較して，1 次枝梗数が少ないが，2 次籾率が高 いこと，「萌えみのり」は「ひとめぼれ」と比較して，1穂 籾数が多く，2 次籾率が高いことなどが示された。「ちほみ のり」や「萌えみのり」に抏いて 2 次籾率が高いことは, 多収要因の 1 つである可能性があるが，品質を悪くする要 因である可能性もある。本研究は単年度の結果なので，今 後, 多収性の品種や品質の優れる品種の形態的特性, お上 びその収量・品質・食味との関連を継続的に調査していく 必要がある。

収量形成に関しては，前期追肥によって両品種群ともに 穂数が増加することにより総籾数が増加した（第 4 表）。 一方，後期追肥が穂数や総籾数に及ぼす影響は僅かであっ た。これは，後期追肥の時期には，穂数や 1 穂籾数がほぼ 決定されているためと推察される。一方，登熟歩合は，早 生品種群においては前期追肥により低下し, 中生品種群に おいても，前期追肥により有意ではないものの低下する傾 向が認められた。これは，前期追肥により総籾数が増加し たためと推察される。千粒重は両品種群ともに後期追肥に よって増加した，後期追肥区においては，総籾数は増加し ないが，葉色值が高くなったことから，1玄米当たりの光 合成量が多くなり，個々の玄米が肥大したのではないかと 推察される，以上の結果，両品種群ともに，前期追肥，後 期追肥によって精玄米重は増加した。詳細にみると，精玄 米重は, 早生品種群では出穂 22 日前の前期追肥で $698 \mathrm{~g} /$ $\mathrm{m}^{2}$, 出穂 8 日前の後期追肥で $636 \mathrm{~g} / \mathrm{m}^{2}$, 中生品種群では出 穂 28 日前の前期追肥で $687 \mathrm{~g} / \mathrm{m}^{2}$, 出穂 14 日前の後期追肥 で $703 \mathrm{~g} / \mathrm{m}^{2}$ であり, 出穂 8 日前の追肥では収量があまり 増加しない傾向にある。これらの結果から，収量を高める のに効果的な追肥時期は出穂 30〜15 日前であろうと推察 される。

東北農研育成品種の特徵をみると,「ちほみのり」は「あ きたこまち」に比べて，4\%の多収であったが，統計的に 有意な差異は認められなかった。一方，育成時における標 肥移植栽培の成績 (太田ら 2016) では,「ちほみのり」は「あ きたこまち」より 5 年間平均で $11 \%$ の多収であった。年 次別にみると，「あきたこまち」の倒伏程度が大きい年次 において，「ちほみのり」は「あきたこまち」より明らか に多収となっている。これらのことから，本試験では「あ きたこまち」の倒伏程度が小さかったために,「ちほみのり」
と「あきたこまち」の収量差は小さかったと判断される。「萌 えみのり」は「ひとめぼれ」より 4\%の多収であった。 13 年間の生産力検定試験・標肥移植栽培に扔ける精玄米重の 平均值は,「萌えみのり」は「ひとめぼれ」より $2 \%$ 多収 であり（福嶌ら 2015），本研究の結果と矛盾することは ないと判断される。「えみのあき」は「ひとめぼれ」より， $6 \%$ の少収であった。育成時に扔ける標肥移植栽培の成績 （梶ら 2013）では,「えみのあき」は「ひとめぼれ」より 5 年間平均で $2 \%$ の少収であり，年次別にみると，「ひとめぼ れ」の倒伏程度が小さい 2 年間は,「えみのあき」は「ひ とめぼれ」より $5 \% ， 6 \%$ の少収となっている。このこと から，「ひとめぼれ」の倒伏が少ない条件においては，「え みのあき」は「ひとめぼれ」より少収である可能性がある。 「萌えみのり」と「えみのあき」を比較すると，「萌えみのり」 は「えみのあき」より，穂数は $4 \%$ 少なく, 1 穂籾数は $14 \%$ 多く，千粒重は $2 \%$ 多く，登熟歩合に差はなく，精玄 米重は $11 \%$ 多かった（第 4 表）。このことから，「萌えみの り」は「えみのあき」より1穂籾数が多いために多収であ ると判断される。ただし，本年度は，8月中旬頃からの天 候が不順であり，「えみのあき」のように出穂の遅い品種 の収量が特に低くなった可能性があるので，「えみのあき」 の少収要因については, 複数年の結果から再評価する必要 がある。

本年度の精玄米の外観品質は, $3.4 \sim 4.3$ の範囲であり, いずれの品種や追肥法も，良好であったと判断される（第 4 表)，その範囲内の差異をみると，前期追肥により，乳白 米がやや増加し，品質がやや低下した，乳白米は，籾数が 多いことにより増加することが広く知られており（月森 2008), 前期追肥は, 総籾数の増加, 乳白米の増加を介し て品質の低下を招いたと推察される。「あきたこまち」や「え みのあき」は品質がやや優れていた，その形態的要因とし ては，同一品種群の中で 2 次籾率が低いことが挙げられる (第 3 表)，なお，本年度は，高温年に顕著にみられる背白 粒の発生はほとんど認められなかったが,「萌えみのり」は, 高温年に背白粒が多発することが東北農研の生産力検定試 験において観察されており，注意する必要がある，食味官 能試験における総合值は，後期追肥により低下寸る傾向が 認められた (第 5 表)。食味は, 玄米蛋白質の増加に伴い 低下することが広く知られており，本研究においても，後 期追肥によって玄米蛋白質が増加し（第 4 表），食味が低 下したと推察される。東北農研育成品種の食味は, 本研究 の結果のみから判断することは難しいが, 育成時の食味官 能試験の結果を考慮すると,「あきたこまち」,「ひとめぼれ」 と同程度と判断される。

以上の結果をまとめると, 東北農研育成 3 品種に適した 追肥時期は，収量性からは出穂 30〜15 日前であるが，前 期追肥は総籾数の増加による品質の低下，後期追肥は玄米 蛋白質含量の増加による食味の低下を招く危険性があっ た。よって, 総合的には, 従来から「あきたこまち」や「ひ 
とめぼれ」について指摘されていたように出穂 25 日前か ら20日前が追肥適期であろうと推察された。本研究は,「あ きたこまち」や「ひとめぼれ」においても倒伏が少ない東 北地域の慣行に近い施肥量で行われたものであった. 東北 農研育成 3 品種は，耐倒伏性に優れていることが育成時に 報告されているので（片岡ら 2007, 梶ら 2013, 太田ら 2016)，「あきたこまち」や「ひとめぼれ」が倒伏しやすい 多肥や直播の条件において安定した多収が期待できる。今 後は, 多肥や直播における収量・品質・食味を詳細に解析 し, 東北農研育成 3 品種に適した多収栽培法を明らかして いく必要がある。

\section{引用文献}

福井清美 - 小林陽 1996. 食味官能検査. 山本隆一 ·堀末登・池田良一 編, イネ育種マニュアル。養賢堂, 東京. 74-76.

福嶌陽 2007. 生育時期別窒素追肥が水稲の形態的形質に及ぼす影響 およびその品種間差異. 日作紀 76: 18-27.

福嶌陽 ·太田久稔・梶亮太・津田直人 2015. 生産力検定試験成績を
利用した水稲の収量形成要因の解析. 日作紀 84: 249-255.

井上正勝 1996. 玄米外観品質. 山本隆一・堀末登・池田良一編, イネ 育種マニュアル.養賢堂, 東京. 115-118.

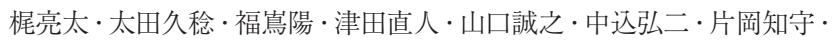
遠藤貴司 ·横上晴郁 2013. いもち病抵抗性極強の直播向き良食味水 稲新品種候補系統「奥羽 407 号」. 東北農業研究センター 2012 年の 成果情報. https://www.naro.affrc.go.jp/project/results/laboratory/tarc/ 2012/112a0_02_02.html (2016/2/5 閲覧).

片岡知守 · 山口誠之 · 遠藤貴司 · 中込弘二 · 滝田正 · 横上晴郁 · 加 藤浩 2007. 直播適性が高い良食味水稲品種「萌えみのり」の育成. 東北農研研報 107: 15-28.

楠田宰 1995. 水稲の収量及び収量構成要素の調查方法について. 植調 29: $138-143$.

松島省三 1977. 稲作診断と増収技術. 農山漁村文化協会, 東京. 1-333.

太田久稔 - 山口誠之 · 福嶌陽 - 梶亮太 - 津田直人 $\cdot$ 中込弘二 ·片岡 知守・遠藤貴司 2016. 多収で直播栽培向きの良食味水稲品種「ち ほみのり」の育成. 東北農研研報 118: 37-48.

月森弘 2008. 気象および移植時期が水稲 ‘コシヒカリ’ の乳白粒発生 に及ぼす影響. 島根農技研報 38: 47-56.

Effects of Nitrogen Topdressing Time on Growth, Yield, Grain Appearance and Eating Quality of the Rice Varieties Bred by Tohoku Agricultural Research Center : Akira Fukushima, Hisatoshi OнтA, Narifumi Yokogami and Naoto Tsuda (NARO Tohoku Agricultural Research Center, Daisen, Akita 014-0102, Japan)

Abstract : The effects of nitrogen topdressing time were investigated in three rice varieties for ready-made meals and restaurants, "Chihominori", "Moeminori" and "Eminoaki", which were bred by NARO Tohoku Agricultural Research Center (TARC). Early heading group "Massigura", "Chihominori" and "Akitakomachi"and medium heading group "Hitomebore", "Moeminori" and "Eminoaki"were also examined. The effects of early topdressing, late topdressing and no topdressing in the three varieties bred by TARC were not significantly different from those in the other varieties. Early topdressing increased the numbers of panicles and spikelets per area, resulting in a higher brown rice yield. Late topdressing slightly increased the number of spikelets per area and thousand grain weight, resulting in a larger brown rice yield. However, early topdressing increased milk white rice, resulting in an inferior grain appearance. Late topdressing increased the nitrogen content of brown rice, resulting in a slightly inferior eating quality. Judging from the yield, grain appearance and eating quality, usual time of nitrogen topdressing was estimated to be appropriate for the three rice varieties made by TARC. Brown rice yield of "Chihominori" was the same as that of "Akitakomachi". That of "Moeminori" was slightly larger and that of "Eminoaki" was slightly smaller than that of "Hitomebore". The three varieties bred by TARC have high lodging resistance and are expected to show a high yield under high nitrogen fertilization and / or direct seeding cultivation where "Akitakomachi" and "Hitomebore" become lodged.

Key words : Grain appearance, Eating quality, Nitrogen topdressing, Rice, Yield. 